Article

\title{
Assessment of the Allelochemical Activity and Biochemical Profile of Different Phenotypes of Picocyanobacteria from the Genus Synechococcus
}

\author{
Zofia Konarzewska ${ }^{1, *}$, Sylwia Śliwińska-Wilczewska ${ }^{1}{ }^{[0}$, Aldo Barreiro Felpeto ${ }^{2}$, \\ Vitor Vasconcelos ${ }^{2,3}$ a and Adam Latała ${ }^{1}$ \\ 1 Division of Marine Ecosystems Functioning, Institute of Oceanography, University of Gdańsk, \\ Av. Piłsudskiego 46, 81-378 Gdynia, Poland; ocessl@ug.edu.pl (S.Ś.-W.); oceal@ug.edu.pl (A.L.) \\ 2 Interdisciplinary Center of Marine and Environmental Research-CIMAR/CIIMAR, University of Porto, \\ Av. General Norton de Matos s/n, 4450-208 Matosinhos, Portugal; aldo.barreiro@gmail.com (A.B.F.); \\ vmvascon@fc.up.pt (V.V.) \\ 3 Department of Biology, Faculty of Sciences, Porto University, Rua do Campo Alegre, 4069-007 Porto, Portugal \\ * Correspondence: zofia.konarzewska@gmail.com
}

Received: 2 March 2020; Accepted: 25 March 2020; Published: 27 March 2020

check for

Abstract: Organisms belonging to Synechococcus sp. genera are observed in all freshwater, brackish, and marine waters of the world. They play a relevant role in these ecosystems, since they are one of the main primary producers, especially in open ocean. Eventually, they form mass blooms in coastal areas, which are potentially dangerous for the functioning of marine ecosystems. Allelopathy could be an important factor promoting the proliferation of these organisms. According to the authors' best knowledge, there is no information on the allelopathic activity and allelopathic compounds exhibited by different Synechococcus sp. phenotypes. Therefore, the research conducted here aimed to study the bioactivity of compounds produced by three phenotypes of Synechococcus sp. by studying their influence on the growth, chlorophyll fluorescence, and photosynthetic pigments of eighteen cyanobacteria and microalgae species. We demonstrated that three different Synechococcus sp. phenotypes, including a phycocyanin (PC)-rich strain (Type 1; green strain) and phycoerythrin (PE)-rich strains containing phycoerythrobilin (PEB) and phycocyanobilin (PCB) (Type 2; red strain and Type 3a; brown strain), had a significant allelopathic effect on the selected species of cyanobacteria, diatoms, and green algae. For all green algae, a decrease in cell abundance under the influence of phenotypes of donor cyanobacteria was shown, whereas, among some target cyanobacteria and diatom species, the cell-free filtrate was observed to have a stimulatory effect. Our estimates of the stress on photosystem II $\left(F_{v} / F_{m}\right)$ showed a similar pattern, although for some diatoms, there was an effect of stress on photosynthesis, while a stimulatory effect on growth was also displayed. The pigment content was affected by allelopathy in most cases, particularly for chlorophyll $a$, whilst it was a bit less significant for carotenoids. Our results showed that Synechococcus sp. Type 3a had the strongest effect on target species, while Synechococcus sp. Type 1 had the weakest allelopathic effect. Furthermore, GC-MS analysis produced different biochemical profiles for the Synechococcus strains. For every phenotype, the most abundant compound was different, with oxime-, methoxy-phenylbeing the most abundant substance for Synechococcus Type 1, eicosane for Synechococcus Type 2, and silanediol for Synechococcus Type 3a.

Keywords: allelochemicals; phytochemicals; picocyanobacteria; Synechococcus sp. 


\section{Introduction}

Picoplanktonic cyanobacteria of the genus Synechococcus are of great importance for the functioning of marine ecosystems, due to their significance in the composition of phytoplankton communities [1]. Moreover, they are capable of producing harmful secondary metabolites [2], as well as creating blooms that play a significant role in the environment, which are enhanced as a result of the increasing eutrophication of coastal ecosystems [1,3] and global warming [4,5]. It is also possible that picocyanobacteria have an advantage over other organisms due to their ability to adapt to changing environmental conditions [2] and their allelopathic activity [6].

The dominant photosynthetic pigments (phycobiliproteins) in phycobilisomes constitute the basis of the classification of organisms from the genus Synechococcus, which is the most abundant picoplanktonic genus in the Baltic Sea [7]. Phycobilisomes of these picoplanktonic cyanobacteria can contain four different phycobiliproteins: phycocyanin (PC), two forms of phycoerythrin (PE) known as PEI and PEII, and allophycocyanin (APC). PC can tie phycoerythrobilin (PEB) and phycocyanobilin (PCB). PEI binds either only PEB or both PEB and PUB, whereas PEII always binds both PEB and PUB [8-10]. Furthermore, research conducted by Six et al. [9] created a classification of marine Synechococcus consisting of three large groups: Type 1 consists of phenotypes with PC; Type 2 consists of phenotypes with a dominance of PEI; and Type 3 incorporates phenotypes with PC and two types of PE, which can be subdivided into different types (from a to d) based on the PEB and PUB ratio, with Type 3a having a low PEB:PUB ratio [9]. All three phenotypes of picocyanobacteria occur in the Baltic Sea [11,12].

One of the reasons why allelopathy is a subject of interest for researchers is because it can favor the dominance of a species in the ecosystem [13]. However, the effect of allelochemicals depends on the nature of the interaction between donor and target organisms and the activity of the chemical compounds responsible for this interaction. Nevertheless, knowledge on the substances excreted by picoplanktonic cyanobacteria of the genus Synechococcus is still scarce. Recently, studies have been conducted on the allelopathic activity of a green strain of Synechococcus, with a higher amount of PC (Type 1) on phytoplankton species occurring in the same environment [2]. This indicates that these picocyanobacteria could constitute a source of allelochemical substances not previously identified. The aim of our work was to determine the bioactivity of compounds produced by a strain from each of the three phenotypes of Synechococcus sp. (Type 1, Type 2, and Type 3); the latter two of which have were been explored. The bioactivity was assessed by studying their influence on the growth, photosynthetic parameters, and pigment composition of coexisting phytoplanktonic species. In addition, a biochemical profile of each strain was obtained by GS-MS analysis.

\section{Results and Discussion}

\subsection{Allelopathic Effect of Different Synechococcus sp. Phenotypes on the Growth of Targeted Species of Phytoplankton}

Our results showed a significant effect of all three phenotypes of Synechococcus sp. on the growth of all target species of cyanobacteria and microalgae, except the green algae Chlorella fusca (Figure 1, Table S1 in Supplementary Materials). Experiments revealed that the filtrate obtained from donor picocyanobacteria, in the majority of cases, had a negative effect on the growth of target species, with the highest inhibition caused by Synechococcus Type 3a (brown strain) (Figure 1). The most significant allelopathic effect was observed for the diatom Skeletonema marinoi (ANOVA, $F_{9.32}=99.0 ; p<0.001$ ) and constituted 77\% (Dunnett HSD, $p<0.001$ ), 35\% (Dunnett HSD, $p<0.001$ ), and 20\% (Dunnett HSD, $p<0.001)$, respectively, of growth observed in the control. Furthermore, the cyanobacterium for which the highest inhibition of growth was observed was Nostoc sp. (ANOVA, $F_{9.32}=283.1 ; p<0.001$ ) and constituted 31\% (Dunnett HSD, $p<0.001$ ), 34\% (Dunnett HSD, $p<0.001$ ), and 33\% (Dunnett HSD, $p<0.001)$, respectively, compared to the control. A positive effect on growth was observed in one cyanobacterium, Aphanizomenon sp., by Synechococcus Type 1 (green strain) and Type 3a (brown strain), and diatoms species Navicula perminuta under the influence of Synechococcus Type 2 (red strain). The 
highest growth was noted for Nitzschia fonticola after the addition of cell-free filtrate of the green strain, which resulted in more than twice the number of cells of the control.
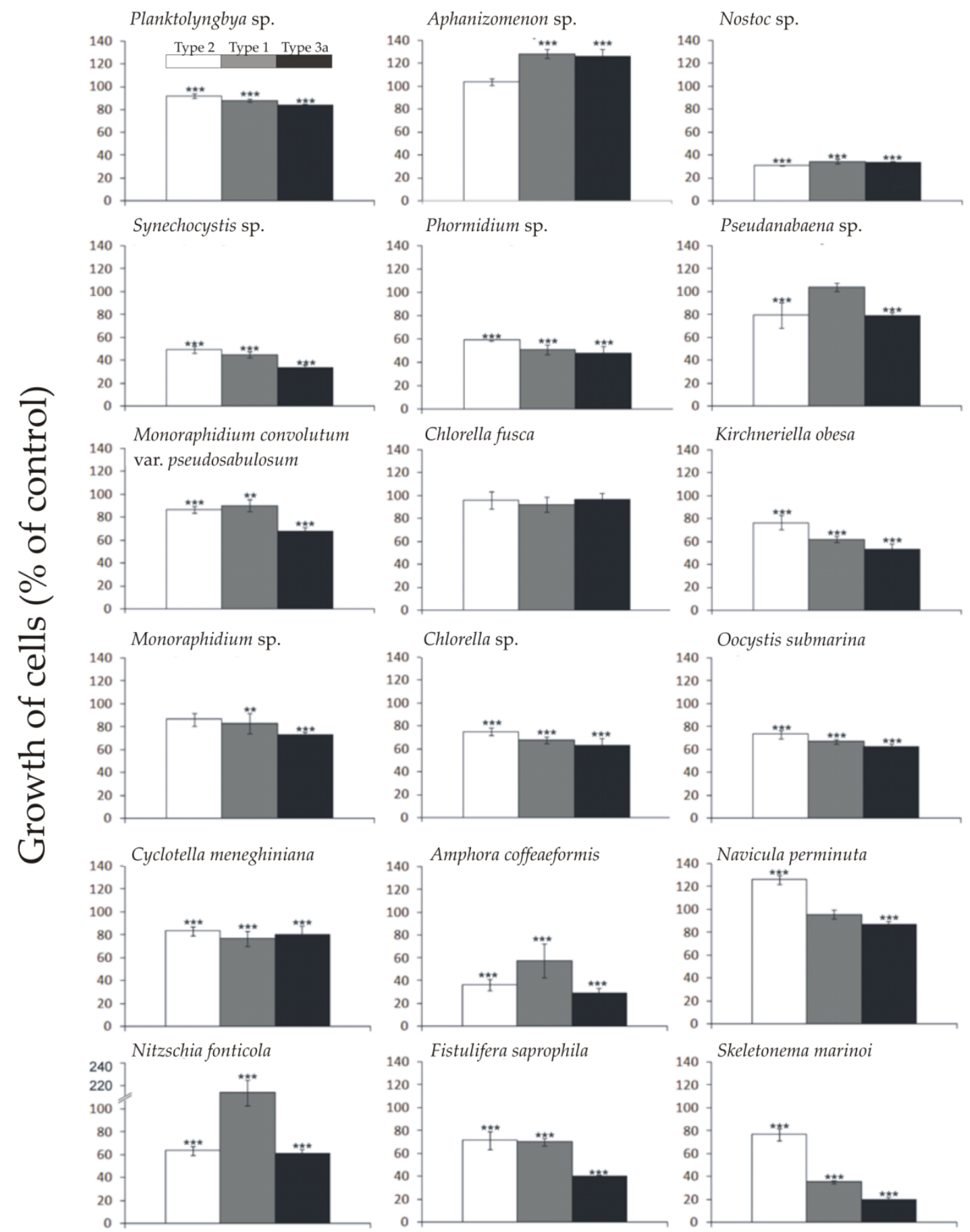

Figure 1. Growth of cells (\% of control) of targeted cyanobacteria and microalgae, after the seventh day of the experiment with the addition of filtrate obtained from cultures of different Synechococcus sp. phenotypes. The values refer to means $(n=3$, mean $\pm \mathrm{SD})$. Asterisk indicates significant difference identified by a post hoc Dunnett test, compared with the control $\left({ }^{*} p<0.05 ;{ }^{* *} p<0.01 ;{ }^{* *} p<0.001\right)$.

In most cases, the highest allelopathic activity was demonstrated for Synechococcus Type 3a (brown strain). This phenotype belongs to cluster 5.1, which includes organisms that do not require an increased amount of nutrients [11]. Moreover, organisms in this clade prefer transparent ocean 
waters [14], and are thus not abundant in relatively nutrient-rich waters of the Baltic Sea. The strong growth-inhibiting response of the target phytoplankton strains to allelopathic compounds produced by the brown Synechococcus strain may have resulted from the geographical avoidance of both producer and target organisms and the consequent lack of adaptation.

Several studies have shown a negative effect of the Synechococcus sp. Type 1 filtrates on different phytoplankton species, such as diatom Navicula perminuta [15], filamentous cyanobacteria Nostoc sp. and Phormidium sp. [16], bloom-forming cyanobacteria Nodularia spumigena [17], and Porphyridium purpureum and Prymnesium parvum [18]. Dominance by certain phytoplankton species in the community can be explained by the inhibition caused in the growth of co-existing species. If other environmental conditions are also favorable, this can lead to blooms of those species. This results in a change of the natural structure of the phytoplankton complex, for example, during the summer in the Baltic Sea $[19,20]$.

It is believed that the plankton community maintains its diversity due to temporal (seasonal) heterogeneity driving them to a permanent non-equilibrium state, preventing species exclusion by a succession of seasonal communities [21]. Some factors contributing to the structuring of these seasonal communities have already been experimentally demonstrated, such as the light gradient [22]. However, allelopathy can also be considered as a driver of the plankton community structure [23]. Nevertheless, the effect of allelochemicals depends on the nature of the interaction between donor and target organisms and the activity of the chemical compounds responsible for this interaction.

In previous studies, it was demonstrated that allelopathic compounds may have self-stimulating properties [24]. Stimulation of the growth of the cyanobacteria Aphanizomenon flos-aquae under the influence of the filtrate from Synechococcus sp. was observed in studies conducted by Śliwińska-Wilczewska et al. [16]. Studies conducted by Bar-Yosef et al. [25] may be helpful in understanding the stimulating properties of allelopathic substances. Research has shown that Aphanizomenon can induce the alkaline phosphatase secretion of co-existing phytoplankton species, as a succession strategy. That is why an increase of target organisms is beneficial for bloom-forming Aphanizomenon.

\subsection{Allelopathic Effect of Different Synechococcus sp. Phenotypes on the Chlorophyll Fluorescence of Studied Species of Phytoplankton}

Our results showed significant effects of all three Synechococcus sp. phenotypes on the maximum PSII quantum efficiency $\left(F_{v} / F_{m}\right)$ of the target species (Table 1, Table S2 in Supplementary Materials). The allelopathic effects on $F_{v} / F_{m}$ were species-specific. Cell-free filtrate inhibited the $F_{v} / F_{m}$ of all studied diatoms and green algae showed the strongest inhibition of the $F_{v} / F_{m}$, except Oocystis submarina, for which a positive effect was observed. However, cyanobacteria, in most cases, showed an increase in the $F_{v} / F_{m}$, suggesting a stimulatory effect of allelopathy. Among these, the highest increase was shown for Phormidium sp. (ANOVA, $F_{6.24}=15.9 ; p<0.001$ ) in response to Synechococcus Type 2 and constituted $158 \%$ of the control (Dunnett HSD, $p<0.001$ ). However, the highest decrease in $F_{v} / F_{m}$ was also observed for cyanobacterium. In Nostoc sp. (ANOVA, $\left.F_{6.24}=11.7 ; p<0.001\right), F_{v} / F_{m}$ dropped to only $29 \%$ of the control (Dunnett HSD, $p<0.001$ ) after being exposed to Synechococcus Type 3a.

Prince et al. [26] showed a significant decrease in the $F_{v} / F_{m}$ fluorescence parameter of the species Akashiwo cf. sanguinea, Amphora sp., Asterionellopsis glacialis, Prorocentrum minimum, and Skeletonema costatumin response to Karenia brevis (dinoflagellate). However, the studies conducted by Śliwińska-Wilczewska et al. [15] did not show a significant influence of diatom Navicula perminuta on the $F_{v} / F_{m}$ value after the addition of filtrate obtained from Synechococcus sp. The filtrate from Synechococcus sp. also decreased the fluorescence parameter of P. purpureum and Stichococcus bacillaris, but increased the $F_{v} / F_{m}$ of P. parvum [18]. Experiments conducted on freshwater species by Kovacs et al. [27] showed a significant decrease in the $F_{v} / F_{m}$ of green alga Scenedesmus quadricauda after the addition of coexisting freshwater picocyanobacteria Cyanobium gracile and Cylindrospermopsis raciborskii. In addition, it was shown that the cell-free filtrate of picocyanobacteria Synechocystis sp. inhibits this same fluorescence parameter of the coexisting microalgae species P. purpureum and Fistulifera sp. [6].Our 
work and the mentioned literature show a predominantly inhibitory effect on this parameter. A low index of photosynthesis parameters is indicative of irregularities in the process of photosynthesis, low physiological conditions, and the impact of potential stress factors on the studied plant organisms [27]. Studies show that moderations in photosynthesis or the influence of chemicals alters fluorescence kinetics and may be an indicator of environmental changes [28]. A decrease of the main physiological process of co-occurring algae species is a competitor strategy, which can determine the domination of this species in the environment. The results showed that the influence of allelochemicals varied, depending on the strain, which may indicate that the composition of the phytoplankton community can heavily influence the nature of allelopathic interactions, as well as the seasonal succession [27].

Table 1. Effect of filtrate from different Synechococcus sp. phenotypes on the chlorophyll fluorescence parameter $F_{v} / F_{m}$ obtained after the seventh day of the experiment. Asterisk indicates significant difference identified by a post hoc Dunnett test, compared with the control $\left({ }^{*} p<0.05 ;{ }^{* *} p<0.01\right.$; $\left.{ }^{* * *} p<0.001\right)$.

\begin{tabular}{|c|c|c|c|}
\hline \multirow{2}{*}{ Target Species } & \multicolumn{3}{|c|}{ Effect on Phenotypes of Synechococcus sp } \\
\hline & Type 1 & Type 2 & Type 3a \\
\hline \multicolumn{4}{|c|}{ Cyanobacteria } \\
\hline Planktolyngbya sp. & $++^{*}$ & 0 & 0 \\
\hline Aphanizomenon sp. & $+* *$ & $+* * *$ & $+* * *$ \\
\hline Nostoc sp. & $-* * *$ & $-* * *$ & $-* * *$ \\
\hline Synechocystis sp. & 0 & 0 & 0 \\
\hline Phormidium sp. & $+* * *$ & $+* * *$ & $+* * *$ \\
\hline Pseudanabaena sp. & $-* * *$ & $-* * *$ & 0 \\
\hline \multicolumn{4}{|c|}{ Green algae } \\
\hline Monoraphidium convolutum var. pseudosabulosum & $-* * *$ & $-* * *$ & $-* * *$ \\
\hline Chlorella fusca & $-* * *$ & $-* * *$ & $-* * *$ \\
\hline Kirchneriella obesa & 0 & $+* *$ & $-{ }^{* *}$ \\
\hline Monoraphidium sp. & $-* * *$ & $-* * *$ & $-* * *$ \\
\hline Chlorella sp. & $-* * *$ & $-* * *$ & $-* * *$ \\
\hline Oocystis cf. submarina & $+* * *$ & $+* * *$ & $+* * *$ \\
\hline \multicolumn{4}{|c|}{ Diatoms } \\
\hline Cyclotella meneghiniana & $-{ }^{*}$ & $-* *$ & $-{ }^{*}$ \\
\hline Amphora coffeaeformis & $-* *$ & 0 & $-* * *$ \\
\hline Navicula perminuta & $-* * *$ & 0 & 0 \\
\hline Nitzschia fonticola & $-* * *$ & 0 & $-* * *$ \\
\hline Fistulifera saprophila & $-* *$ & 0 & $-* * *$ \\
\hline Skeletonema marinoi & 0 & 0 & $-* * *$ \\
\hline
\end{tabular}

2.3. Allelopathic Effect of Different Synechococcus sp. Phenotypes on the Photosynthetic Pigments of Studied Species of Phytoplankton

This study has shown that the filtrate from all phenotypes of Synechococcus sp. negatively affected the content of chlorophyll $a$ and carotenoid pigments of the cyanobacteria Phormidium sp. and Nostoc sp., green algae M. convolutum var. pseudosabulosum, K. obesa, Monoraphidium sp., and O. submarina, as well as thediatoms A. coffeaeformis, N. fonticola, and F. saprophila (Table 2, Table S3 in Supplementary Materials). The largest decrease of chlorophyll $a$ was found for the species Monoraphidium sp. with filtrate from phenotype $3 a(6 \%$ relative to the control, $t$-test, $p<0.001)$ and the largest decrease of carotenoids was found for the species M. convolutum var. pseudosabulosum (16\% relative to the control, 
$t$-test, $p<0.001)$. The green algae were shown to be the group most susceptible to allelopathic effects. The decrease in the content of pigments also appeared to be associated with the decrease in the number of cells of these organisms, with the exception of $N$. fonticola, which showed an increase in the number of cells under the influence of Synechococcus Type 1. Among the positive effects detected for the chlorophyll $a$ content, the highest increase was demonstrated for cyanobacterium from the genus Planktolyngbya. There were no positive effects on carotenoid pigments observed. In general, carotenoids were much less affected than chlorophyll $a$.

In line with our results, Suikkanen et al. [20] observed a significant decrease in the chlorophyll a content of Rhodomonassp. after being exposed to filtrate from cyanobacteria $A$. flos-aquae and $N$. spumigena. Additionally, a significant reduction of chlorophyll $a$ in Phormidium sp., Rivularia sp., and $N$. spumigena was demonstrated in response to the filtrate from Synechococcus sp. [16,17]. Inhibition of the chlorophyll $a$ value shows a drop in the efficiency of photosynthesis, which demonstrates the activity of the cell's defense mechanism and response to stress factors [28,29].

Table 2. Effect of filtrate from different Synechococcus sp. phenotypes on photosynthetic pigments (chlorophyll $a$ and carotenoids) obtained after the seventh day of the experiment. Asterisk indicates significant difference, compared with the control $\left({ }^{*} p<0.05 ;{ }^{* *} p<0.01 ;{ }^{* * *} p<0.001\right)$.

\begin{tabular}{|c|c|c|c|c|c|c|}
\hline \multirow{4}{*}{ Target Species } & \multicolumn{6}{|c|}{ Effect on Phenotypes of Synechococcus sp. } \\
\hline & \multicolumn{2}{|c|}{ Type 1} & \multicolumn{2}{|c|}{ Type 2} & \multicolumn{2}{|c|}{ Type 3a } \\
\hline & \multicolumn{6}{|c|}{ Photosynthetic Pigments } \\
\hline & Chl $a$ & Car & Chl $a$ & Car & Chl $a$ & Car \\
\hline \multicolumn{7}{|c|}{ Cyanobacteria } \\
\hline Planktolyngbya sp. & $+* *$ & 0 & $+*$ & $-*$ & $+* *$ & 0 \\
\hline Aphanizomenon sp. & $+*$ & 0 & 0 & 0 & $+* *$ & 0 \\
\hline Nostoc sp. & $-*$ & $-* *$ & $-*$ & $-*$ & $-*$ & $-* *$ \\
\hline Synechocystis sp. & $-*$ & 0 & $-*$ & 0 & $-*$ & 0 \\
\hline Phormidium sp. & $-* * *$ & $-* * *$ & $-* * *$ & $-* * *$ & $-* * *$ & $-*$ \\
\hline Pseudanabaena sp. & $-*$ & $-* * *$ & $-*$ & 0 & $-* * *$ & $-* * *$ \\
\hline \multicolumn{7}{|c|}{ Green algae } \\
\hline Monoraphidium convolutum var. pseudosabulosum & $-*$ & $-* *$ & $-*$ & $-* *$ & $-* *$ & $-* * *$ \\
\hline Chlorella fusca & $-*$ & $-*$ & 0 & 0 & $-*$ & 0 \\
\hline Kirchneriella obesa & $-* * *$ & $-* *$ & $-* * *$ & $-* *$ & $-* * *$ & $-* *$ \\
\hline Monoraphidium sp. & $-* * *$ & $-* *$ & $-* * *$ & $-* *$ & $-* * *$ & $-* * *$ \\
\hline Chlorella sp. & $-* * *$ & 0 & $-* * *$ & 0 & $-* * *$ & 0 \\
\hline Oocystis cf. submarina & $-* * *$ & $-* *$ & $-* *$ & $-* *$ & $-* *$ & $-* *$ \\
\hline \multicolumn{7}{|c|}{ Diatoms } \\
\hline Cyclotella meneghiniana & $-{ }^{*}$ & 0 & 0 & 0 & $-* * *$ & $-* *$ \\
\hline Amphora coffeaeformis & $-* * *$ & $-* * *$ & $-* * *$ & $-* * *$ & $-* *$ & $-* * *$ \\
\hline Navicula perminuta & $-{ }^{*}$ & $-*$ & 0 & 0 & $-{ }^{*}$ & $-*$ \\
\hline Nitzschia fonticola & $-* * *$ & $-* *$ & $-* * *$ & $-* *$ & $-* * *$ & $-* * *$ \\
\hline Fistulifera saprophila & $-* * *$ & $-* * *$ & $-* * *$ & $-* * *$ & $-* * *$ & $-* * *$ \\
\hline Skeletonema marinoi & 0 & $-* *$ & 0 & 0 & $-* * *$ & $-* * *$ \\
\hline
\end{tabular}

\subsection{GC-MS Analysis}

GC-MS analysis identified the most abundant chemical compounds from every cell-free filtrate from Synechococcus sp. Type 1, Type 2, and Type 3a (Table 3) that did not occur in f/2 medium and thus may potentially be allelopathic substances. All substances present in the filtrates are shown in 
Table S4 in the Supplementary Materials, as well as the GC-MS chromatogram profiles of $\mathrm{f} / 2$ medium and three phenotypes of Synechococcus sp. in Figures S1-S4. Twenty-two chemical compounds not detected in the $\mathrm{f} / 2$ medium were found in Synechococcus Type 1 (green strain). The most abundant one was eicosane, 10-methyl- (Figure 2), with the peak area of $64.98 \%$. Synechococcus Type 2 (red strain) showed 10 compounds that were not present in the $f / 2$ medium. In this strain, the most abundant was oxime-, methoxy-phenyl-, with a peak area of $12.91 \%$. GC-MS analysis revealed only five compounds produced by Synechococcus Type 3a (brown strain), with the most abundant of them being silanediol, dimethyl, with a $13.03 \%$ peak area. In previous studies, compounds detected in algae having antimicrobial properties included inter alia fatty acids, hydrocarbons, phenols, terpenes, and indoles [30-32], and some of these substances also occurred in the analysis carried out in this study. Chemicals from these classes were proven to have an antimicrobial and antialgal role, and can also be ranked among phytochemicals.

Table 3. The most abundant phytochemicals identified in different phenotypes of picocyanobacteria from the genus Synechococcus Type 1 (green strain), Type 2 (red strain), and Type 3a (brown strain) by GC-MS.

\begin{tabular}{|c|c|c|c|c|c|c|c|c|c|}
\hline \multirow{2}{*}{$\begin{array}{l}\text { Name of } \\
\text { Compound }\end{array}$} & \multirow[b]{2}{*}{ RT } & \multirow[b]{2}{*}{ Molecular } & \multirow[b]{2}{*}{ MW } & \multicolumn{2}{|c|}{ Type 1} & \multicolumn{2}{|c|}{ Type 2} & \multicolumn{2}{|c|}{ Type 3a } \\
\hline & & & & $\begin{array}{c}\text { Peak } \\
\text { Area \% }\end{array}$ & SI & $\begin{array}{c}\text { Peak } \\
\text { Area \% }\end{array}$ & SI & $\begin{array}{c}\text { Peak } \\
\text { Area \% }\end{array}$ & SI \\
\hline Silanediol, dimethyl- & 4.301 & $\mathrm{C}_{2} \mathrm{H}_{8} \mathrm{O}_{2} \mathrm{Si}$ & 92 & ND & ND & ND & ND & 13.03 & 97 \\
\hline $\begin{array}{c}\text { Oxime-, } \\
\text { methoxy-phenyl- }\end{array}$ & 8.444 & $\mathrm{C}_{8} \mathrm{H}_{9} \mathrm{NO}_{2}$ & 151 & 0.79 & 83 & 12.91 & 83 & 4.51 & 83 \\
\hline Eicosane, 10-methyl- & 15.060 & $\mathrm{C}_{21} \mathrm{H}_{44}$ & 296 & 64.98 & 96 & 6.73 & 94 & ND & ND \\
\hline
\end{tabular}

$\mathrm{RT}=$ retention time, $\mathrm{MW}=$ molecular weight, $\mathrm{ND}=$ not detected, and SI = NIST (mass spectral libraries) Match Factors.
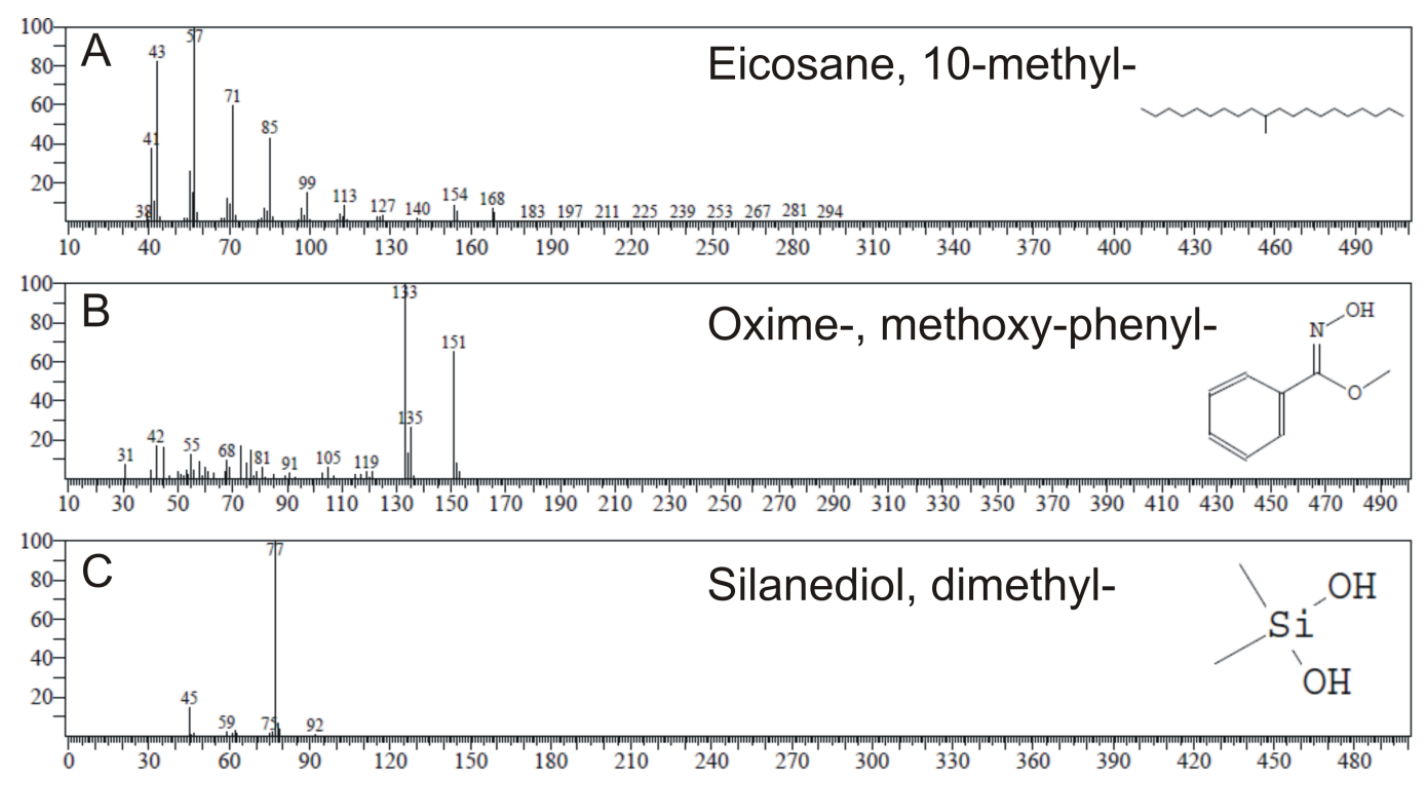

Figure 2. GC-MS spectrum of identified compounds which dominated in the cultures of different Synechococcus sp. phenotypes, including Type 2 (A), Type 1 (B), and Type 3a (C), and were not present in the $\mathrm{f} / 2$ medium.

Previous studies carried out using Gas Chromatography-Mass Spectrometry (GC-MS) analysis detected eicosane in species of red algae Laurencia obtusa var. pyramidata [33], brown algae Turbinaria ornata [34], and Cystoseira barbata, which was proven to show antimicrobial activity [35]. In addition, oxime-, methoxy-phenyl- found in Synechococcus Type 2 was identified in the bacteria Sorangium 
cellulosum [36] and Pseudomonas aeruginosa [37], fungi species Aspergillus terreus [38], and the leaf extract of Alstonia scholaris [39], and was proven to have antimicrobial, antibacterial, and antifungal properties. Furthermore, the most abundant substance in Synechococcus Type 3a was proven to be silanediol, which has protease inhibitor properties [40]. Moreover, studies conducted by Madsen et al. [41] have proven that silanediols represent a novel zinc binding group (ZBG) with properties that can be used for the development of histone deacetylase inhibitors, which have an important role inter alia in apoptosis [42].

Picocyanobacteria have also been rarely studied with respect to their potential as producers of novel bioactive allelopathic compounds. Our results indicate that different phenotypes of Synechococcus sp. may serve as a potential source of interesting bioactive compounds, whose characterization requires detailed investigation.

\section{Materials and Methods}

\subsection{Studied Species}

In this study, the experiments were conducted using Synechococcus strains from Type 1 (green strain), Type 2 (red strain), and Type 3a (brown strain), obtained from the Culture Collection of Baltic Algae (CCBA) as strains Synechococcus sp. (BA-120), Synechococcus sp. (BA-124), and Synechococcus sp. (BA-132), respectively. Eighteen species of cyanobacteria, green algae, and diatoms (Table 4) were cultivated in the CCBA at the Institute of Oceanography, University of Gdańsk, Poland [43], to be tested as target strains for investigation of the allelopathic activity of Synechococcus.

Table 4. Microalgae and cyanobacteria species tested for allelopathic activity.

\begin{tabular}{|c|c|}
\hline Target Species & Identification in CCBA Collection \\
\hline \multicolumn{2}{|c|}{ Cyanobacteria } \\
\hline Planktolyngbya sp. & BA-50 \\
\hline Aphanizomenon sp. & BA-69 \\
\hline Nostoc sp. & BA-81 \\
\hline Synechocystis sp. & BA-121 \\
\hline Phormidium sp. & BA-141 \\
\hline Pseudanabaena sp. & BA-142 \\
\hline \multicolumn{2}{|c|}{ Chlorophyta } \\
\hline Monoraphidium convolutum var. pseudosabulosum & BA-17 \\
\hline Chlorella fusca & BA-18 \\
\hline Kirchneriella obesa & BA-51 \\
\hline Monoraphidium sp. & BA-165 \\
\hline Chlorella sp. & BA-167 \\
\hline Oocystis cf. submarina & BA-172 \\
\hline \multicolumn{2}{|c|}{ Bacilariophyta } \\
\hline Cyclotella meneghiniana & BA-10 \\
\hline Amphora coffeaeformis & BA-16 \\
\hline Navicula perminuta & BA-30 \\
\hline Nitzschia fonticola & BA-34 \\
\hline Fistulifera saprophila & BA-56 \\
\hline Skeletonema marinoi & BA-98 \\
\hline
\end{tabular}




\subsection{Culture Condition}

Cyanobacterial and microalgal cultures were grown in $\mathrm{f} / 2$ medium [44]. Culture media was prepared with Baltic Sea water (salinity $8 \%$ ) filtered through glass fiber filters (Whatman GF/C) and autoclaved. All organisms were grown under the conditions of photosynthetic active light (PAR) of $10 \mu \mathrm{mol}$ photons $\mathrm{m}^{-2} \mathrm{~s}^{-1}$ with the photoperiod L:D 16:8, at $18{ }^{\circ} \mathrm{C}$ and $8 \%$. All cultures were acclimated to experimental conditions for 7 days. Light was provided by an artificial light source (Cool White 40W, Sylvania, Wilmington, MA, USA). Measurements of the PAR radiation intensity were made using the Li-Cor meter, model LI-189, with a cosine collector.

\subsection{Determination of the Allelopathic Effect of Cell-Free Filtrates}

Allelopathic effects were tested according to a method proposed by Suikkanen et al. [19], with modifications. Experimental treatments were prepared by adding $10 \mathrm{~mL}$ of the cell-free filtrate $(\mathrm{f} / 2$ medium in controls) to 25-mL Erlenmeyer flasks containing $10 \mathrm{~mL}$ of cell suspensions of the targeted species. In all experiments, the initial Chl $a$ concentration in the cultures was $0.4 \mu \mathrm{g} \mathrm{Chl} a \mathrm{~mL}^{-1}$. Synechococcus sp. strains were filtered through a $0.45-\mu \mathrm{m}$ filter (Macherey-Nagel MN GF-5). Tests were conducted in triplicate and the results of the experiments are presented as the mean value of three independent measurements.

\subsection{Cell Density Assays}

Cell abundances of cyanobacteria and microalgae were estimated with previously determined linear regression models on the basis of the optical density (OD) and number of cells $\left(\mathrm{NmL}^{-1}\right)$ in the cultures. Estimates of the cell abundance of picocyanobacteria, green algae, and diatoms were carried out using the BD Accuri ${ }^{\mathrm{TM}} \mathrm{C} 6$ Plus flow cytometer. Filamentous cyanobacteria cells were counted using a Tomic SFC-18 light microscope and the Bürker chamber, and were counted from 48 large squares [45]. Obtained data were used to fit a linear regression model of the number of cells and optical density (Table 5). Cell abundances were calculated on the seventh day of the exposure of target cells in experimental and control cultures.

Table 5. Linear regression and correlation coefficients $(r)$ used to calculate the number $(N)$ of studied picocyanobacteria, cyanobacteria, green algae, and diatom cells in cultures based on optical density (OD) measurements.

\begin{tabular}{ccc}
\hline Studied Strain & Linear Regression & Correlation Coefficient $(r)$ \\
\hline BA-120 & $N=4242096 \cdot O D-35834$ & 0.97 \\
\hline BA-124 & $N=93029379 \cdot$ OD -98415 & 0.99 \\
\hline BA-132 & $N=139120177 \cdot$ OD -44353 & 0.99 \\
\hline BA-50 & $N=74916153 \cdot O D+46981$ & 0.92 \\
\hline BA-69 & $N=6716526 \cdot O D-86633$ & 0.96 \\
\hline BA-81 & $N=39891877 \cdot O D-11899$ & 0.95 \\
\hline BA-121 & $N=163917381 \cdot O D-246275$ & 0.98 \\
\hline BA-141 & $N=86779699 \cdot O D-44781$ & 0.98 \\
\hline BA-142 & $N=126415680 \cdot O D+100972$ & 0.98 \\
\hline BA-17 & $N=24943668 \cdot O D-263873$ & 0.99 \\
\hline BA-18 & $N=14395782 \cdot O D+100101$ & 0.97 \\
\hline BA-51 & $N=12365968 \cdot O D-246229$ & 0.99 \\
\hline BA-165 & $N=13120468 \cdot O D+10489$ & 0.99 \\
\hline BA-167 & $N=3678299 \cdot O D+274144$ & 0.93 \\
\hline
\end{tabular}


Table 5. Cont.

\begin{tabular}{ccc}
\hline Studied Strain & Linear Regression & Correlation Coefficient $(r)$ \\
\hline BA-172 & $N=3363550 \cdot O D+91273$ & 0.98 \\
\hline BA-10 & $N=8775538 \cdot O D-1251$ & 0.98 \\
\hline BA-16 & $N=4385135 \cdot O D+15527$ & 0.98 \\
\hline BA-30 & $N=6412449 \cdot O D-8836$ & 0.97 \\
\hline BA-34 & $N=8050792 \cdot O D+17824$ & 0.98 \\
\hline BA-56 & $N=7326981 \cdot O D-57789$ & 0.99 \\
\hline BA-98 & $N=38103552 \cdot O D+75013$ & 0.97 \\
\hline where $N-$ cells in $1 \mathrm{~mL}$ of medium and OD-optical density of the culture.
\end{tabular}

\subsection{Fluorescence Assay}

The effects of the filtrate of three different Synechococcus sp. phenotypes on the chlorophyll fluorescence of target species were determined using the maximum PSII quantum efficiency $-F_{v} / F_{m}$ (where $F_{v}$-the difference between the maximum and minimum fluorescence and $F_{m}$-the maximum fluorescence) [46]. The measurements were conducted using a Pulse Amplitude Modulation (PAM) fluorometer (FMS1, Hansatech, King's Lynn, United Kingdom) after 7 days of the experiment. Samples were filtered through glass fiber filters (Whatman GF/C, Saint Louis, MO, USA). Before measurement, the filtered sample was kept in the dark for approximately $10 \mathrm{~min}$ [15].

\subsection{Pigments Assay}

Photosynthetic pigments of target species were examined for the control and experiments with additions of the cell-free filtrate obtained from three different Synechococcus sp. phenotypes after 7 days of exposure. In the experiment, pigment extraction $(4 \mathrm{~mL}$ of the material) was carried out in experimental flasks in $2 \mathrm{~mL}$ of $90 \%$ acetone in the dark and at a low temperature of $-60{ }^{\circ} \mathrm{C}$ for about 1 hour. After this time, the extract was centrifuged for $1 \mathrm{~min}$ at 13,000 rpm min ${ }^{-1}$. Absorbance measurements were then carried out in $1 \mathrm{~cm}$ glass cuvettes on a Becker spectrophotometer model DU 530 at wavelengths of 480,665 , and $750 \mathrm{~nm}$. For the determination of chlorophyll $a$, different formulas of cyanobacteria, green algae, and diatoms was used, as described by Jeffrey and Humphrey [47]. The concentration of carotenoid pigments was calculated using the formula employed by Strickland and Parsons [48].

\subsection{GC-MS Analysis}

GC-MS analysis was carried out on a Shimadzu QP 2017 SE LOG 149 system comprising a gas chromatograph interfaced to a mass spectrometer (GC-MS) instrument employing the following conditions: column Zebron 5MSi (30 m, I.D $0.25 \mathrm{~mm} \times 0.25 \mu \mathrm{m}$, Phenomenex, Part no.: 7HG-G018-11, Serial nr. 357092), operating in electron impact mode at $70 \mathrm{eV}$; helium $(99.999 \%)$ was used as carrier gas at a constant flow of $1.5 \mathrm{~mL} \mathrm{~min}^{-1}$ and an injection volume of $0.5 \mathrm{EI}$ was employed (split ratio of 10:1) with an injector temperature of $300^{\circ} \mathrm{C}$; ion-source temperature $260^{\circ} \mathrm{C}$. The oven temperature was programmed from $30^{\circ} \mathrm{C}$ (isothermal for $5 \mathrm{~min}$ ), with an increase of $20^{\circ} \mathrm{C} \mathrm{min}{ }^{-1}$, to $300{ }^{\circ} \mathrm{C}$, ending with a $3 \mathrm{~min}$ isothermal at $300{ }^{\circ} \mathrm{C}$. Mass spectra were taken at $70 \mathrm{eV}$, a scan-interval of $0.5 \mathrm{~s}$, and fragments from 40 to $550 \mathrm{Da}$ [49]. Compounds were identified by fitting coefficients (SI) using the NIST library ver. 14.

\subsection{Statistical Analyses}

Repeated measures ANOVA was used to test the effect of Synechococcus strains on the growth and fluorescence of the targeted species onday0, 1, 3 (data not shown), and 7 of the experiment. A post hoc Dunnett test was used to determine significant differences between the control and the experimental treatments. One-way ANOVA was used to test the effect of picocyanobacterial filtrates on 
the chlorophyll $a$ and carotenoid pigments in control and experimental cultures on the seventh day of the experiment. Data are reported as the mean \pm standard deviation (SD). Levels of significance were ${ }^{*} p<0.05,{ }^{* *} p<0.01$, and ${ }^{* * *} p<0.001$. The statistical analyses were performed using the Statistica ${ }^{\circledR}$ 13.1 software.

\section{Conclusions}

This work demonstrated the significant allelopathic effect of all three phenotypes of picoplanktonic cyanobacteria Synechococcus sp. on the growth and photosynthetic activity of selected species of Baltic cyanobacteria, green algae, and diatoms. GC-MS analysis of the cell-free filtrate showed the presence of chemical compounds that may potentially be allelopathic substances, of which the most dominant ones all had either antimicrobial or cell-damaging properties. Phenotypes of Synechococcus sp. displayed interesting and valuable allelopathic activities and further analysis of the substances they produce is essential, particularly due to the potential role of allelochemicals in structuring the plankton community.

Supplementary Materials: The following are available online at http://www.mdpi.com/1660-3397/18/4/179/s1, Figure S1: Chromatogram that shows the results of the analysis of sample of $\mathrm{f} / 2$ medium prepared using HS-SPME, Figure S2: Chromatogram that shows the results of the analysis of sample of phenotype Type 1 of Synechococcus sp. prepared using HS-SPME, Figure S3: Chromatogram that shows the results of the analysis of sample of phenotype Type 2 of Synechococcus sp. prepared using HS-SPME, Figure S4: Chromatogram that shows the results of the analysis of sample of phenotype Type 3a of Synechococcus sp. prepared using HS-SPME, Table S1:Number of cells of studied cyanobacteria and microalgae obtained after 7th day of the experiment for control and culture with the addition of filtrate obtained from cultures of cyanobacteria Synechococcus sp. (BA-120, BA-124 and BA-132), Table S2: Value of fluorescence of chlorophyll $a\left(F_{\mathrm{v}} / F_{\mathrm{m}}\right.$ parameter $)$ of studied cyanobacteria and microalgae obtained after 7th day of the experiment for control and culture with the addition of filtrate obtained from cultures of cyanobacteria Synechococcus sp. (BA-120, BA-124 and BA-132), Table S3: Value of photosynthetic pigments (chlorophyll $a$ and carotenoid pigments) of studied cyanobacteria and microalgae obtained after 7th day of the experiment for control and culture with the addition of filtrate obtained from cultures of cyanobacteria Synechococcus sp. (BA-120, BA-124 and BA-132), Table S4: Phytochemicals identified in different phenotypes of picocyanobacteria from the genus Synechococcus Type 1 (green strain), Type 2 (red strain), and Type 3a (brown strain) by GC-MS. The compounds found in both the $\mathrm{f} / 2$ medium and picocyanobacterial cultures are highlighted in italics.

Author Contributions: Conceptualization, Z.K.; data curation, Z.K.; formal analysis, Z.K., S.Ś.W., and A.B.F.; investigation, Z.K. and S.Ś.-W.; methodology, Z.K. and S.Ś.-W.; supervision, S.Ś.-W., A.B.F., V.V., and A.L. writing, Z.K. All authors have read and agreed to the published version of the manuscript.

Funding: This research was founded by BMN grant number 539-O140-B416-20, FCT Projects UIDB/04423/2020 and UIDP/04423/2020.

Acknowledgments: The authors would like to thank the anonymous Reviewers and Kreis Li, Assistant Editor for their valuable comments and suggestions to improve the quality of the paper.

Conflicts of Interest: The authors declare no conflicts of interest.

\section{References}

1. Sorokin, P.Y.; Sorokin, Y.I.; Boscolo, R.; Giovanardi, O. Bloom of picocyanobacteria in the Venice lagoon during summer-autumn 2001: Ecological sequences. Hydrobiologia 2004, 523, 71-85. [CrossRef]

2. Śliwińska-Wilczewska, S.; Maculewicz, J.; Barreiro, A.; Latała, A. Allelopathic and bloom-forming picocyanobacteria in a changing world. Toxins 2018, 10, 48. [CrossRef] [PubMed]

3. Li, F.; Qiu, Z.; Zhang, J.; Liu, C.; Cai, Y.; Xiao, M.; Zhu, L. Temporal variation of major nutrients and probabilistic eutrophication evaluation based on stochastic-fuzzy method in Honghu Lake, Middle China. Sci. China Technol. Sci. 2019, 62, 417-426. [CrossRef]

4. Flombaum, P.; Gallegos, J.L.; Gordillo, R.A.; Rincon, J.; Zabala, L.L.; Jiao, N.; Karl, D.M.; Li, W.K.; Lomas, M.W.; Veneziano, D. Present and future global distributions of the marine Cyanobacteria Prochlorococcus and Synechococcus. PNAS 2013, 110, 9824-9829. [CrossRef] [PubMed]

5. Dutkiewicz, S.; Morris, J.J.; Follows, M.J.; Scott, J.; Levitan, O.; Dyhrman, S.T.; Berman-Frank, I. Impact of ocean acidification on the structure of future phytoplankton communities. Nat. Clim. Change 2015, 5, 1002. [CrossRef] 
6. Barreiro, A.; Śliwińska-Wilczewska, S.; Klin, M.; Konarzewska, Z.; Vasconcelos, V. Temperature-dependent impacts of allelopathy on growth, pigment, and lipid content between a subpolar strain of Synechocystis sp. CCBA MA-01 and coexisting microalgae. Hydrobiologia 2019, 835, 117-128.

7. Mazur-Marzec, H.; Sutryk, K.; Kobos, J.; Hebel, A.; Hohlfeld, N.; Błaszczyk, A.; Toruńska, A.; Kaczkowska, M.J.; Łysiak-Pastuszak, E.; Kraśniewski, W.; et al. Occurrence of cyanobacteria and cyanotoxin in the Southern Baltic Proper. Filamentous cyanobacteria versus single-celled picocyanobacteria. Hydrobiologia 2013, 701, 235-252. [CrossRef]

8. Six, C.; Thomas, J.C.; Thion, L.; Lemoine, Y.; Zal, F.; Partensky, F. Two novel phycoerythrin-associated linker proteins in the marine cyanobacterium Synechococcus sp. strain WH8102. J. Bacteriol. 2005, 187, 1685-1694. [CrossRef]

9. Six, C.; Thomas, J.C.; Garczarek, L.; Ostrowski, M.; Dufresne, A.; Blot, N.; Scanlan, D.J.; Partensky, F. Diversity and evolution of phycobilisomes in marine Synechococcus spp.: A comparative genomics study. Genome Biol. 2007, 8, R259. [CrossRef]

10. Larsson, J.; Celepli, N.; Ininbergs, K.; Dupont, C.L.; Yooseph, S.; Bergman, B.; Ekman, M. Picocyanobacteria containing a novel pigment gene cluster dominate the brackish water Baltic Sea. ISME J. 2014, 8, 1892. [CrossRef]

11. Haverkamp, T.H.; Schouten, D.; Doeleman, M.; Wollenzien, U.; Huisman, J.; Stal, L.J. Colorful microdiversity of Synechococcus strains (picocyanobacteria) isolated from the Baltic Sea. ISME J. 2009, 3, 34-408. [CrossRef] [PubMed]

12. Śliwińska-Wilczewska, S.; Cieszyńska, A.; Maculewicz, J.; Latała, A. Ecophysiological characteristics of red, green, and brown strains of the Baltic picocyanobacterium Synechococcus sp.- - laboratory study. Biogeosciences 2018, 15, 6257. [CrossRef]

13. Legrand, C.; Rengefors, K.; Fistarol, G.O.; Graneli, E. Allelopathy in phytoplankton-biochemical, ecological and evolutionary aspects. Phycologia 2003, 42, 406-419. [CrossRef]

14. Herdman, M.; Castenholz, R.W.; Waterbury, J.B.; Rippka, R. Form-genus XIII. The Archaea and the Deeply Branching and Phototrophic Bacteria. In Synechococcus. Bergey's Manual of Systematic Bacteriology, 2nd ed; Boone, D.R., Castenholz, R.W., Garrity, G.M., Eds.; Springer: New York, NY, USA, 2001; Volume 1, pp. 508-512.

15. Śliwińska-Wilczewska, S.; Pniewski, F.; Latała, A. Allelopathic activity of the picocyanobacterium Synechococcus sp. under varied light, temperature and salinity conditions. Int. Rev. Hydrobiol. 2016, 101, 69-77. [CrossRef]

16. Śliwińska-Wilczewska, S.; Maculewicz, J.; Barreiro, A.; Vasconcelos, V.; Latała, A. Allelopathic activity of picocyanobacterium Synechococcus sp. on filamentous cyanobacteria. J. Exp. Mar. Biol. Ecol. 2017, 496, 16-21. [CrossRef]

17. Barreiro, A.; Śliwińska-Wilczewska, S.; Złoch, I.; Vasconcelos, V. Light-dependent cytolysis in the allelopathic interaction between picoplanktic and filamentous cyanobacteria. J. Plankton R. 2018, 40, 165-177. [CrossRef]

18. Śliwińska-Wilczewska, S.; Barreiro, A.; Maculewicz, J.; Sobczyk, A.; Vasconcelos, V.; Latała, A. Allelopathic activity of the picocyanobacterium Synechococcus sp. on unicellular eukaryote planktonic microalgae. Mar. Freshw. Res. 2018, 69, 1472-1479. [CrossRef]

19. Suikkanen, S.; Fistarol, G.O.; Granéli, E. Allelopathic effects of the Baltic Cyanobacteria Nodularia spumigena, Aphanizomenon flos-aquae and Anabaena lemmermannii on algal monocultures. J. Exp. Mar. Biol. Ecol. 2004, 308, 85-101. [CrossRef]

20. Suikkanen, S.; Engström-Öst, J.; Jokela, J.; Sivonen, K.; Viitasalo, M. Allelopathy of Baltic Sea cyanobacteria: No evidence for the role of nodularin. J. Plankton Res. 2006, 28, 543-550. [CrossRef]

21. Malchow, H. Spatio-temporal pattern formation in nonlinear non-equilibrium plankton dynamics. Proc. $R$. Soc. Lond. Biol. 1993, 251, 103-109.

22. Huisman, J.; Jonker, R.R.; Zonneveld, C.; Weissing, F.J. Competition for light between phytoplankton species: Experimental tests of mechanistic theory. Ecology 1999, 80, 211-222. [CrossRef]

23. Barreiro, A.; Roy, S.; Vasconcelos, V. Allelopathy prevents competitive exclusion and promotes phytoplankton biodiversity. Oikos 2018, 127, 85-98.

24. Suikkanen, S.; Fistarol, G.O.; Grane'li, E. Effects of cyanobacterial allelochemicals on a natural plankton community. Mar. Ecol. Prog. Ser. 2005, 287, 1-9. [CrossRef] 
25. Bar-Yosef, Y.; Sukenik, A.; Hadas, O.; Viner-Mozzini, Y.; Kaplan, A. Enslavement in the water body by toxic Aphanizomenon ovalisporum, inducing alkaline phosphatase in phytoplanktons. Curr. Biol. 2010, 20, 1557-1561. [CrossRef]

26. Prince, E.K.; Myers, T.L.; Kubanek, J. Effects of harmful algal blooms on competitors: Allelopathic mechanisms of the red tide dinoflagellate Karenia brevis. Limnol. Oceanogr. 2008, 53, 531-541. [CrossRef]

27. Kovács, A.W.; Tóth, V.R.; Pálffy, K. The effects of interspecific interactions between bloom forming cyanobacteria and Scenedesmus quadricauda (chlorophyta) on their photophysiology. Acta Biol. Hung. 2018, 69, 210-223. [CrossRef]

28. Kumar, K.S.; Dahms, H.U.; Lee, J.S.; Kim, H.C.; Lee, W.C.; Shin, K.H. Algal photosynthetic responses to toxic metals and herbicides assessed by chlorophyll $a$ fluorescence. Ecotoxicol. Environ. Saf. 2014, 104, 51-71. [CrossRef]

29. Machado, M.D.; Lopes, A.R.; Soares, E.V. Responses of the alga Pseudokirchneriella subcapitata to long-term exposure to metal stress. J. Hazard. Mater. 2015, 296, 82-92. [CrossRef]

30. Mayer, A.M.S.; Hamann, M.T. Marine pharmacology in 2001-2002: Marine compounds with anthelmintic, antibacterial, anticoagulant, antidiabetic, antifungal, anti-inflammatory, antimalarial, antiplatelet, antiprotozoal, antituberculosis, and antiviral activities; affecting the cardiovascular, immune and nervous systems and other miscellaneous mechanisms of action. Comp. Biochem. Physiol. Part C 2005, 140, 265-286.

31. Rodríguez-Meizoso, I.; Jaime, L.; Santoyo, S.; Cifuentes, A.; García-Blairsy Reina, G.; Senorans, F.J.; Ibáñez, E. Pressurized fluid extraction of bioactive compounds from Phormidium species. J. Agr. Food Chem. 2008, 56, 3517-3523. [CrossRef]

32. Plaza, M.; Santoyo, S.; Jaime, L.; García-Blairsy Reina, G.; Herrero, M.; Señoráns, F.J.; Ibáñez, E. Screening for bioactive compounds from algae. J. Pharm. Biomed. Anal. 2010, 51, 450-455. [CrossRef] [PubMed]

33. Güven, K.C.; Coban, B.; Erdugan, H. A Chemical Research on Three Red Algae Gracilaria bursa-pastoris, Phyllophora crispa and Laurencia obtusa var. pyramidata. Asian J. Chem. 2014, 26, 6118-6120. [CrossRef]

34. Deepa, S.; Sujatha, K.; Velmurugan, D. The Identification of Bioactive Compounds from Turbinaria ornata (Turner) J. Agaradh and Computational Studies. Pharmacogn. J. 2019, 11, 873-883. [CrossRef]

35. Ozdemir, G.; Horzum, Z.; Sukatar, A.; Karabay-Yavasoglu, N.U. Antimicrobial activities of volatile components and various extracts of Dictyopteris membranaceae and Cystoseira barbata from the coast of Izmir, Turkey. Pharm. Biol. 2006, 44, 183-188. [CrossRef]

36. Xu, F.; Tao, W.Y.; Sun, J. Identification of volatile compounds released by myxobacteria Sorangium cellulosum AHB103-1. Afr. J. Microbiol. Res. 2011, 5, 353-358.

37. Altaee, N.; Kadhim, M.J.; Hameed, I.H. Detection of volatile compounds produced by Pseudomonas aeruginosa isolated from UTI patients by gas chromatography-mass spectrometry. Int. J. Curr. Pharm. Res. 2017, 7, 8-24.

38. Mohammed, G.J.; Kadhim, M.J.; Hussein, H.M. Characterization of bioactive chemical compounds from Aspergillus terreus and evaluation of antibacterial and antifungal activity. IJPPR 2016, 8, 889-905.

39. Swamy, N.T.; Rosaiah, G.; Babu, K.; Kumar, K.V. A study on phytochemical composition, GC-MS analysis and anti-microbial potential of methanolic leaf extract of Alstonia scholaris (1.) R. BR. Int. J. Pharm. Sci. Res. 2019, 10, 747-755.

40. Sieburth, S.M.; Chen, C.A. Silanediol protease inhibitors: From conception to validation. Eur. J. Org. Chem. 2006, 2, 311-322. [CrossRef]

41. Madsen, A.S.; Kristensen, H.M.; Lanz, G.; Olsen, C.A. The effect of various zinc binding groups on inhibition of histone deacetylases 1-11. ChemMedChem 2014, 9, 614-626. [CrossRef]

42. Eckschlager, T.; Plch, J.; Stiborova, M.; Hrabeta, J. Histone deacetylase inhibitors as anticancer drugs. Int. J. Mol. Sci. 2017, 18, 1414. [CrossRef] [PubMed]

43. Latała, A.; Jodłowska, S.; Pniewski, F. Culture Collection of Baltic Algae (CCBA) and characteristic of some strains by factorial experiment approach. Algol. Stud. 2006, 122, 137-154. [CrossRef]

44. Guillard, R.R. Culture of phytoplankton for feeding marine invertebrates. In Culture of Marine Invertebrate Animals; Springer: Boston, MA, USA, 1975; pp. 29-60.

45. Guillard, R.R.; Sieracki, M.S. Counting cells in cultures with the light microscope. Algal Cult. Tech. 2005, 239-252.

46. Campbell, D.; Hurry, V.; Clarke, A.K.; Gustafsson, P.; Öquist, G. Chlorophyll fluorescence analysis of cyanobacterial photosynthesis and acclimation. Microbiol. Mol. Biol. R. 1998, 62, 667-683. [CrossRef] 
47. Jeffrey, S.T.; Humphrey, G.F. New spectrophotometric equations for determining chlorophylls a, b, c1 and c2 in higher plants, algae and natural phytoplankton. Biochem. Physiol. Pflanz. 1975, 167, 191-194. [CrossRef]

48. Strickland, J.D.; Parsons, T.R. A practical handbook of seawater analysis. Can. J. Fish. Aquat. Sci. 1972, 167, $1-310$.

49. Paranthaman, R.; Praveen, K.P.; Kumaravel, S. GC-MS analysis of phytochemicals and simultaneous determination of flavonoids in Amaranthus caudatus (Sirukeerai) by RP-HPLC. J. Anal. Bioanal. Tech. 2012, 3,147 .

(C) 2020 by the authors. Licensee MDPI, Basel, Switzerland. This article is an open access article distributed under the terms and conditions of the Creative Commons Attribution (CC BY) license (http://creativecommons.org/licenses/by/4.0/). 